\title{
Post-industrial, post-socialist or new productive city? Case study of the spatial and functional change of the chosen Warsaw industrial sites after 1989
}

Katarzyna Sadowy ${ }^{1 *}$ and Adam Lisiecki ${ }^{2}$

\begin{abstract}
Introduction: In 1989 in Poland the transition period was initiated, which caused a profound change not only of a political and institutional nature, but also an economic change of local labour markets and urban space. One of the most prominent change was de-industrialization, encompassing also the capital city.

Case description: The paper describes the change of an area in Praga, developed for decades on the basis of industry and in last 25 years losing this character. 29 former factories have been identified and described, varying in current functions - from modern factories, to residential areas, to unused sites. There are several actors present: municipal, enterprises (both of local, country and international level), free-lancers and NGOs. The sites' transformation analysis was based on the public records, focus groups and interviews and professional experience.

Discussion and evaluation: Authors present the changes in ownership and use and discuss the role of municipal and private actors in the structural and spatial change in the area. The case is presented within the framework of the productive city model and the relations between the local and supra-local context of the re-development.

Conclusions: Analyzed area may profit of the delay in public and private investments by establishing new productive ventures, based on the existing tangible and intangible heritage of the place. Public sector should be the main player in such urban adaptive re-use. However, the authors found no coherent municipal policy towards the chosen sites, their heritage and potential. The existence of such a potential for modern form of a productive city and the need for new policies answering better to grass-root activities and socio-economic potential of the area is the main conclusion of the analysis.
\end{abstract}

Keywords: Urban development, Post-industrial city, Productive city, Municipality, Heritage, Localism, Adaptive re-use

\section{Introduction}

Post-industrial sites and heritage have been a focus for many researchers and urban decision makers during last decades. The literature covers a broad variety of research, from the general approach of trends (e.g. O'Connor and Wynne 2017; Carter 2016), to the analysis of specific cities of various scale (Savitch 2014; Holgersen 2015; Lever 2017; Duvernoy et al. 2018). Two main reasons may be

*Correspondence: ksadow@sgh.waw.pl

${ }^{1}$ Warsaw School of Economics, Warsaw, Poland

Full list of author information is available at the end of the article found for such an interest: abundance of post-industrial sites from the nineteenth and twentieth century, as a result of huge deindustrialization in the European and US cities since the 1970s; and recognition of the industrial heritage, its cultural and architectural values. At first, as factories and warehouses were losing their former use, they became the liability in urban structure, adding to the crisis of the city centers and lowering the quality of city life. However, in the late twentieth and early twenty-first century two phenomena occurred in the cities of global North. One was an appearance of the paradigm of intangible economy, part to the information era, knowledge 
society and creative class (Castells 1997, 2011; Florida 2005). The other consisted of several innovative municipal policies. Local decision-makers wanted to revive the shrinking cities, bring about their "renaissance" and make living in them attractive again. In doing so they focused on the most desired and very mobile inhabitants-creative class and high-skilled professionals.

High level of "livability" or urban attractiveness depended heavily, according to the decision makers, on the cultural life, uniqueness and more a less authentic heritage. Post-industrial buildings and sites provided an ideal space for such added value of the city. They provided unique and authentic heritage of the urban history, more and more exotic as the real industry continued to disappear from the urban landscape. Factories and warehouses consisted of various architectural forms, from small entities, ideal for alternative local clubs or cafes to the grand-scale interiors suitable for modern art or artistic events, spaciousness otherwise existing only in churches and railway stations. Therefore, post-industrial traits of the city provide greater spatial and architectural variety, opening several possibilities for more varied and complex urban environment. Some were adapted as lofts, not of the original kind, suitable for low-income independent artists and free-lancers, but for the new creative class, with higher income and a taste for the good balance between originality and bourgeois comfort. If the buildings themselves were not attractive enough, the sites, after dismantling former factories, were also a good opportunity for constructing modern, large-scale, highquality venues. They were often located nearby city centers all well connected by the public transport.

Examples of such practices are quite numerous and present in practically all European countries. Among the most famous is the new Guggenheim Museum in Bilbao by Frank Gehry, an example of the new iconic architecture used to erase the industrial past and create so called "Bilbao effect" (Plaza 2007); on another end of scale highly praised New Tate Modern by Herzog and de Meron, celebrating the original electric station in which it was located. A plethora of large- and small-scale cultural investments exist between these two giants, to name just a few and less known: Centrale Montemartini in Rome, Italy, Center for Contemporary Art in Radom, Poland or Espace Fondation EDF, Paris, France, all in former power stations. One of the biggest transformations of such kind was Manufactura in Lodz, Poland, where Museum of Modern Art is accompanied in a huge nineteenth century site by commercial mall with a multiplex and a luxurious spa hotel. The current continuation of these trend is represented by the investment of La Seine Musicale, part of the Grand Paris plan, located in a former Renault industrial site on the Seine.
However, this trend seems to be slowly reverted by a new one, appearing both in socio-economic European policy and in the grass-root movements. These trends comprise two main oppositions, which are used as a theoretical framework for the analyses in this paper: global versus local and consumerist city versus productive city. These oppositions result in following questions: What are the current use of the former industrial sites? What is the potential of such sites of re-introducing the production into the cities? How heritage can be used to enhance local societies and in situ capital instead of creating the attraction for international tourism or gentrification processes? A case study of factories in Warsaw will be analyzed to find some answers regarding these current urban challenges. The analyzed factories are located in a chosen area in right-bank part of the city, called Praga. Presented case study will serve as an attempt to broaden our current knowledge in this area. The results, within the limits presented in the paper, may be valid for the academia, and also for the decision makers and practitioners, especially in CEE countries.

\section{Theoretical background, analytical framework and methodology}

Transition period and current policies

In 1989 Poland began the process of transition which led the country to be an efficient market-driven economy and a member of European Union 15 years later. Transformation encompassed most of economic and social areas of life. The first period was marked with a high unemployment and inflation. Several reforms were put into action to cope with the public and external debts, inefficient economy and unstable currency. They proved to be successful in macroeconomic terms, but they were also met with some criticism and social dissatisfaction. 25 years later debates persist regarding the necessity to privatize state-owned enterprises and to deeply deindustrialize the whole country. This paper is not the place to continue this debate or re-open aforementioned questions. We simply describe such situation as a context of the case study. Location of the Praga districts in Warsaw is presented on Fig. 1, whereas it should be mentioned that usually Warsaw dwellers refer to Praga meaning the whole right-bank part of the city.

The transition period coincided with the trends encompassing Europe and many developed countries. It was the transformation from the economy of production to the intangible economies, digital, knowledge-based and services-driven. In Poland the scale of deindustrialization was one of the most significant in Europe, not only in well-known industrial centers such as Lodz and Silesia, but also in the capital city. Between 1994 and 2001 in Warsaw the share of inhabitants 


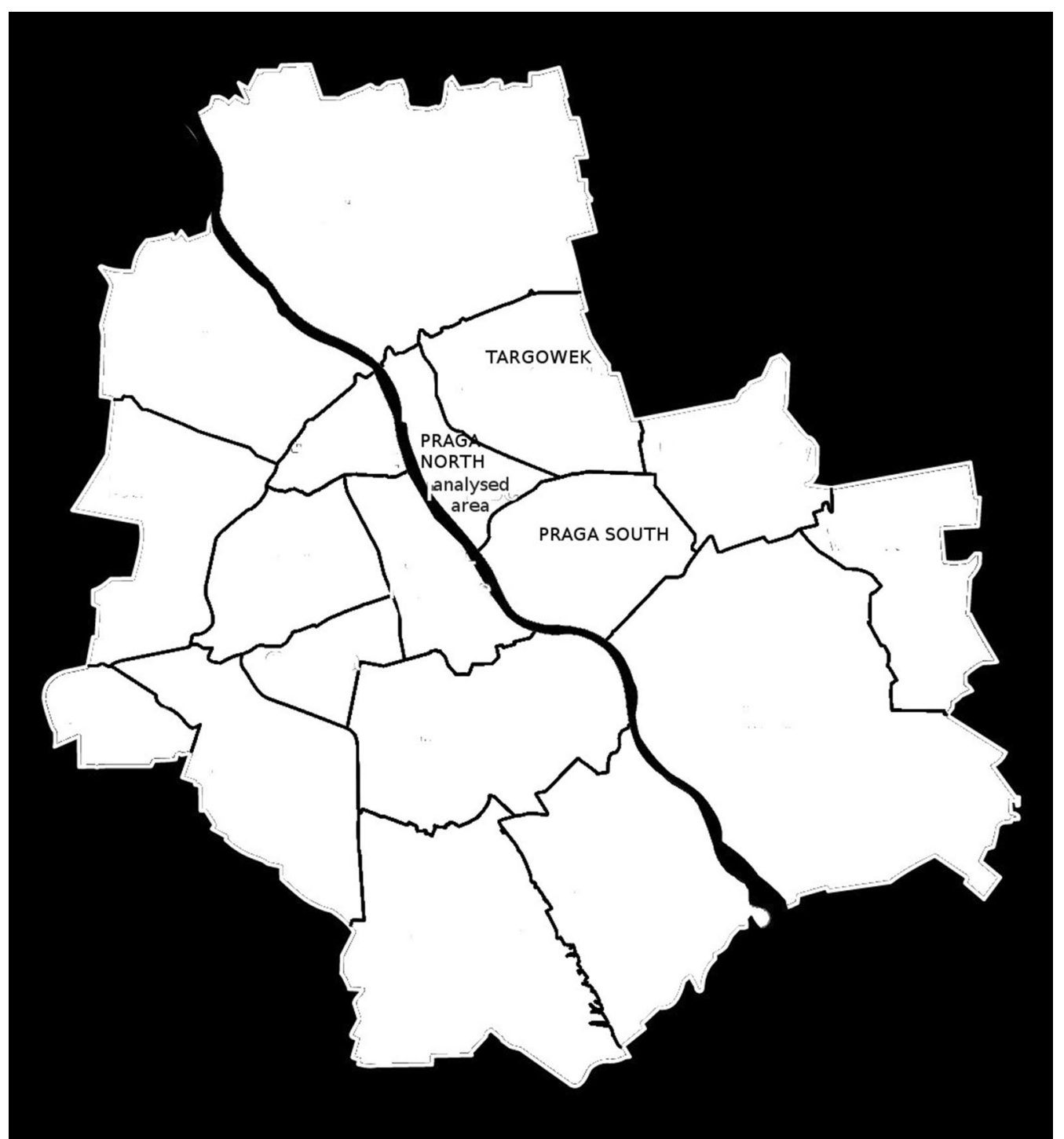

Fig. 1 Warsaw and Praga districts (Source: own work on common resources)

employed in production sector decreased from $25.6 \%$ of the total labor force to $14.8 \%$, representing a decline even bigger than in elsewhere in Europe. In the corresponding time period in such post-socialist cities as Budapest or Prague there was decrease from 18.1 to $14.4 \%$ and from 14.8 to $10.5 \%$ respectively. In Paris the decrease was from 8.4 to $6.1 \%$, as the final part of decades of deindustrialization (Gorzelak and Jalowiecki 2007). In total numbers in Berlin in 1990384 thousand were employed in the industry, while in 1997 only 167 thousand. In Paris the number decreased from 576 thousand in 1962 to 134 thousand in 1999 and in Warsaw from 239 thousand in 1971 to 120 thousand in 2004 (Gorzelak et al. 2009).
In global economy, it is also the period of strong belief in market self-regulations, the shrinking role of state and the conviction of the leading role of innovation and creative class. It influenced significantly Polish urban planning and policies. The period of 1990s and early 2000s in Warsaw was characterized by the urban policy of laissezfaire regarding the land use and new investments. At that time, the post-socialist heritage, including state-owned industry, seemed to be rather a burden than an asset for the future development. Such kind of policy, or rather lack of it, enticed the investors to pick the low-hanging fruit first, namely, to construct new office districts for international companies replacing former factories and warehouses in Mokotów, Wola and Ursus districts on the 
left bank of Vistula. Then, when international companies' presence empowered the middle class, came the investments in housing.

In last few years potential of the left bank districts decreased, making way to the hunt for new business opportunities elsewhere. At the same time urban policies involved more direct actions and investments from the public sector. Some argue their main goal was to create more attractive business environment, others stress social benefits and inclusiveness. Whatever the goal, new public investments appeared on the right bank. The most crucial is the second metro line, connecting the analyzed area with city center in approx. $10 \mathrm{~min}$. There are also new cultural institutions, e.g. Museum of Praga and incubators for the creative class, Creativity Center at Targowa Street. Such private enterprises as Google Campus and creative cluster Soho also improve the image of the district. All these phenomena may be placed within a framework of contradicting approaches: global versus local and consumerism versus production, as explained below.

\section{Global versus local}

The concept of global cities appeared within the general analysis of globalization processes. Again, the time of Polish transition coincided with the moment where the paradigm of globalization and of the global role of some cities was extremely strong. Opening Poland to the world, after decades of semi-isolation behind the "iron curtain", made competing for this global role even more attractive. Generic architecture replacing buildings from twentieth century seemed modern and worldly. Attracting Western tourists became part of the must-do for municipalities. Mobility of capital, knowledge and people, after centrally-controlled life seemed, and of course to some extent really was, the best opportunity which could ever happen.

In the late 1990s and early years 2000 a lot of economists and sociologists focused on intangible elements of economy and social relations (e.g. Castells 1996; Drucker 2001). However, the reality of space was always present in this narrative, e.g. as in Sassen perspective. It has taken even more force lately, as Sassen states that the resources needed for global economic activities are "deeply embedded in place". She also states that such approach "allows us to recover the concrete, localized processes through which globalization exists" (Sassen 2016).

Still, this approach is also embedded in global perspective. Urban life quality was often a category implemented in urban policies to attract the hyper mobile class of highend professionals, inventors and investors. Lately, the localist movement and localism ideas emerged as another voice in this discussion (e.g. Katz and Nowak 2018; Zukin et al. 2016; Hess and Gottlieb 2009). They focus on a "mix" of land use and social groups and on local societies, instead of the dominant global creative class. Within this approach there is also a new focus on heritage and identity of place. It is more and more perceived as an element of social well-being, embedded in local societies. Thus, use of the existing assets, including heritage, become more connected to the grass-root movements and alternative economic models (Geppert 2014; Patti and Polyák 2017).

Some approaches aim at reconciling the global and local perspective, rather than to present them as contradictory. As Voisey and O'Riordan point out, in some arguments "[globalization] is not about the destruction of the locality in favor of greater homogeneity. Rather, it is about the greater interconnection and relativism between localities, economies, polities and cultures" (O`Riordan 2001). Some of the most global cities are also cities with strong local communities and neighborhoods. In economic terms it is expressed in the existence of local, small-scale entrepreneurship, successfully competing (locally) with local, national and international chains (Zukin et al. 2016). In institutional terms local development may profit from the international, globalized relations and markets if the local public administration is effective, strong and flexible, as well as willing to cooperate with various stakeholders (Katz and Nowak 2018).

The growth of the cities and their high productivity has been an area of interest for several researchers and practitioners, dating as early as the works of Xenophon. Some follow the arguments of Hume's about the desire for luxury, others, as Jacobs, provide arguments for the constant change, which we may see in terms of Schumpeterian need for innovations (Schumpeter 2010). Kennedy finds the Keynesian theory especially fruitful in terms of urban growth, as it "combines the need to provide for a community level of consumption and to generate new investments", arguably involving supra-local capital and entrepreneurial network (Keynes 1936; Kennedy 2011).

Therefore, we argue that strong local economy and development embedded in local assets does not have to be opposite to more interconnectedness and private investments also of an international character. However, as we will present in further part of the paper, it seems necessary to provide policies for the local entrepreneurship and neighborhoods if they should profit from such transition from being a periphery into becoming the area of a more metropolitan and international character.

\section{Consumerist city versus productive city}

Discussion about production or consumption as the main driving force in economy is at least as old as the times of Adam Smith. It is said that short before David Hume`s death he had a vivid dispute with the most famous 
economist of all times. In this dispute Hume argued that people needed luxury spending as an incentive to work. Smith, on the other hand, perceived luxury spending as an employment of unproductive labor (Kennedy 2011). Probably the keenest insight into the matter is provided by Thomas Veblen and his leisure class theory (Veblen 1899).

However, these centuries old discussion has many sides and many contemporary voices. Jane Jacobs added a valued narrative in her "Economy of the cities" (Jacobs 1970), where she proclaimed mixed and varied environment as more productive and effective in economic terms then huge monoculture, including of course cities relying on the dominant job-provider, such as a huge factory. Later events, including the infamous Detroit decline but also other studies confirmed her theory (Glaeser et al. 1992). Consumption is also perceived by some authors as a significant force behind the urban revival or development, to some extent replacing production which played this role since the industrial revolution. As Glaeser, Kolko and Saiz argue, mobility of firms makes the success of cities dependent more and more on cities' role as centers of consumption (Glaeser et al. 2003).

An inspiring version of localism and local production is a concept of "urban village". As Clement Homs argues "the success of an urban village depends, above all, on the policy of creating jobs in urban villages. Thus, the urban village must unite a very diversified economic activity" (Homs 2007). The heated debate about "the Bilbao effect" provides us with several arguments against a new monoculture, based on the attractive institution, but in fact, an object of a sophisticated form of consumption (Gómez and González 2001; Plaza 2000, 2008; Gomez 1998).

New productive city may also be called "a city of making, title of one of several UE projects aiming at new forms of urban development (City of making 2018). According to the project report "urban manufacturing: involves the transformation of physical materials; employs labor, tools and/or machines; results in a product; involves 'making' at scale as part of a business model and discounts the one-off production usually associated with the creation of art pieces or hobbyists making for themselves; is embedded in its urban context, as the activity involves a web of supporting services, such as logistics, finance, design, and is linked to a market". As the authors state "these principles encompass a range of activities, including those commonly considered to be manufacturing activity and identified as such in the Statistical Classification of Economic Activities in the European Community (NACE) industrial classification system" but "it is important to look wider than the sector as classified in NACE". It is an approach which seems highly fruitful for our analysis and we will go back to it in our conclusions. It is very much related also to a new or re-newed small-scale production or high-skilled manual labor, which may be located between production and consumption. There are several examples of new forms of entrepreneurship, providing high quality goods or services, from local breweries, to varied kind of repairing workshops, to small scale fashion or graphic design and production. Some of such ventures comprise an element of gentrification processes, where the new wave of inhabitants is accompanied by modern gastronomy, fashion, high-end bike or car repairs, barbers and so on. Some encompass the new possibilities for the long-term local inhabitants and/or entrepreneurs and artisans to employ their skills in new ventures or to find new markets (Ocejo 2017; Perruchini 2018). This kind of entrepreneurship however depends on the "making" skills, from the actual production to repairing or upgrading goods. The tangible expression of this type of economic activities is the presence of local workshops, studio and ateliers.

\section{Case study—Praga district and 29 industrial sites Short history of Praga}

The process of establishing Warsaw as the capital of Poland started in the sixteenth century but it was not until the eighteenth century when it was fully realized (Kula 2011). Praga has been part of the city since the late eighteenth century, till then it existed as an independent town. From the beginning it was a less favored part of the capital city, with less investment, and with inhabitants of lower skills and income. According to current administrative regulations, there are two districts named Praga, North and South. The analyzed area consists if the oldest preserved part, North Praga. It encompasses subdistricts called Old Praga, New Praga, Szmulowizna and Michalow.

The study area underwent several phases of the industrialization, the first one beginning in the nineteenth century, with the peak of new factories and workers quarters constructed in the late nineteenth and early twentieth century. Next intensive stage of industrialization happened between the world wars, after Poland had regained its independence in 1918. In the period of centrallyplanned economy all factories in Praga became stateowned. Several of them had to be refurbished, others had to be modernized or even rebuilt. In some of them pre-war production continued, others became stateinspired and state-controlled cooperatives of artisanship and related services after the WWII. Some factory sites served as warehouses. Few factories went through the modernization process enhancing the $\mathrm{R}+\mathrm{D}$ functions, few others were demolished to provide space for new residential buildings. Bigger factories were constructed in 
newly urbanized areas, located north and east from the analyzed locations, among them there were factories in Targówek district (so called Industrial Targówek).

In spite of these transformation processes Praga North, and especially the analyzed area, retained its spatial structure and architectural character. It consists of the dense quarters of typical nineteenth century town houses, with small inner courtyards and of the factory sites of various sizes, some covering several town blocks. Typical feature of Praga is also the presence of small stores, providing convenient space for grocery shops and everyday services. It is the only part of nineteenth century Warsaw preserved during the WWII, whereas the historical part on the left river bank was almost utterly destroyed. At the same time, it used to be a neglected heritage after the war for several reasons. In the socialist state, typical urban structure of the nineteenth century, capitalist city was not something to preserve and honor as a heritage. As a result, it lingered for decades in the same state it was in 1945, slowly degrading. In the transition period after 1989 public and private investments were concentrated on the left river bank, from the first metro line to the new museums and theaters to new and vast office districts. New housing investment were also rarer in the study area then in the outskirts of Warsaw or more attractive districts on the left bank of the river.

As a result, Praga retained much of its original architecture, character, and identity, even as the industrial sites gradually were losing their functions. Today, the analyzed area provides a good case study for the alternative use of former industrial district, different from the late twentieth century paradigm of transforming former factories into cultural centers and post-industrial areas into a housing districts for higher middle class and creative class. Such kind of investment are in fact already present in Praga, though in a yet restricted number (e.g. at Szwedzka and Ząbkowska street).

Production, as presented before, decreased severely in Warsaw in terms of number of jobs. It is also the case of Praga North district. In 2003 20\% of the employed were working in the industrial sector in 2003, in 2015 the share decreased to only $5 \%$, which presents a loss of 4204 industrial jobs. The total number of jobs in the district however did not change significantly, due to the increased number of employed in the sector of social services, including public administration, social security, education, health-care and social work, thus creating the prominent structural change in the labor market in Praga North (Sadowy 2018).

\section{Sites characteristic, applied and possible future interventions}

We chose 29 factory sites located in the described area, mostly constructed between 1890 and $1939 .{ }^{1}$ They were later remodeled, reconstructed and/or supplemented by new buildings. The analyzed characteristics comprise: localization of the sites; size of the plot; technical state of the buildings; heritage value and legal protection (or lack of thereof); ownership; functions of the site as in 1989 and currently. Used sources are: municipal data base; archive research including public registers, newspapers and advertisement from relevant period; on-site analysis; focus groups and public discussions organized by Museum of Praga in years 2015-2017; informal and semi-structured interviews with municipal managers, Praga inhabitants and local activists.

The complete list of the analyzed sites is presented in Table 1, together with all indicators used in the analysis.

The sites vary strongly in terms of scale. It was measured based on the administrative and functional information, namely if part of the site had housing function (usually at the front) separated from the rest of the plot it was excluded from the total size for the analysis purposes. The smallest site covers approx. $500 \mathrm{~m}^{2}$, the biggest one-more than 55 thousand $\mathrm{m}^{2}$. There are three sites smaller than $1000 \mathrm{~m}^{2}, 12$ between 1000 and $2000 \mathrm{~m}^{2}, 3$ between 2 and 5 thousand $\mathrm{m}^{2}, 5$ between 5 and 10 thousand $\mathrm{m}^{2}$, one of approx. 15 thousand $\mathrm{m}^{2}$ and 5 bigger than 30 thousand $\mathrm{m}^{2}$, one above 55 thousand $\mathrm{m}^{2}$. Size of the sites is presented in Table 1. It is an apt illustration of the how varied, complex and non-homogenous is the industrial heritage of Praga, even if we analyze only the sites from the period covering last decade of nineteen century and three decades of twentieth century. The most significant group, however, approximately a half of all analyzed sites comprises the plots of 1000-2000 $\mathrm{m}^{2}$.

The heritage value of the buildings themselves as well as the urban form and composition they create also varies. From the legal perspective, the sites consist of three groups, approx. of the same number. Eight of 29 has no legal protection. Nine are in the communal record of monuments kept by City of Warsaw, one is in the register of monuments as a whole, rest of the sites consist of various combination of all three, some being both in the register and in the communal record., some protected only in part.

In our opinion legal situation of heritage protection reflects indeed an architectural value of the buildings. These with no formal protection represent in fact

${ }^{1}$ Three of them were constructed in its present form after the WWII, one shortly before 1890 . 
Table 1 List of the analyzed sites

\begin{tabular}{|c|c|c|c|c|c|c|}
\hline \multirow[t]{2}{*}{ No } & \multirow[t]{2}{*}{ Address } & \multirow{2}{*}{$\begin{array}{l}\text { Size group } \\
\text { (sq.m. } \\
\text { approx.) }\end{array}$} & \multirow[t]{2}{*}{ Heritage protection } & \multicolumn{2}{|l|}{ Function of the site } & \multirow[t]{2}{*}{ Ownership } \\
\hline & & & & $\ln 1989$ & In early 2019 & \\
\hline 1 & 11 listopada 10a & $1001-2000$ & $\mathrm{crm}$ & Production & Multi-functional & Private \\
\hline 2 & 11 listopada 22 & $1001-2000$ & $\mathrm{crm}$ & Services & Multi-functional & Municipally-owned \\
\hline 3 & Białostocka 42 & $1001-2000$ & $\mathrm{crm}$ & Production & Multi-functional & Private \\
\hline 4 & Grodzieńska 21/29 & $5001-10,000$ & None & Production & Multi-functional & Perpetual usufruct ${ }^{c}$ \\
\hline 5 & Grodzieńska 51 & $1001-2000$ & $\mathrm{crm}$ & Production & Unused & Municipally-owned \\
\hline 6 & Inżynierska $5 b$ and $5 c$ & $1001-2000$ & $\mathrm{crm}+$ none & Production & Unused & Private \\
\hline 7 & Jadowska 2 & $500-1000$ & None & $\begin{array}{l}\text { Production with } \\
\text { residential function } \\
\text { above }\end{array}$ & Production & Perpetual usufruct \\
\hline 8 & Kawęczyńska 36 & $5001-10,000$ & $\mathrm{crm}+$ none & Production & Educational & Perpetual usufruct \\
\hline 9 & Kawęczyńska 9/11/13 & $2001-5000$ & $\mathrm{crm}+$ none & Production & Residential & Perpetual usufruct \\
\hline 10 & Kłopotowskiego 11 & $1001-2000$ & $\mathrm{crm}+$ none & Offices & Multi-functional & Perpetual usufruct \\
\hline 11 & Konopacka 17 & $1001-2000$ & $\mathrm{crm}$ & Production & Unused, very bad repair & Municipally-owned \\
\hline 12 & Konopacka 19 & $1001-2000$ & None & Production & Unused & Private \\
\hline 13 & Krowia 6 & $1001-2000$ & None & Offices & Residential & Perpetual usufruct \\
\hline 14 & Łomżyńska 37 & $2001-5000$ & None & Unclear $^{\mathrm{a}}$ & Production & $\begin{array}{l}\text { Co-ownership } \\
\text { Private/municipally-owned }\end{array}$ \\
\hline 15 & Objazdowa 1/Wojnicka 2 & $30,000-50,000$ & rom + crm + none & Production & Multi-functional & $\begin{array}{l}\text { Perpetual usufruct (state- } \\
\text { owned) }\end{array}$ \\
\hline 16 & Objazdowa 2 & $5001-10,000$ & $\mathrm{rom}+\mathrm{crm}$ & Warehouse & $\begin{array}{l}\text { Unused, planned to be } \\
\text { converted into a cluster } \\
\text { for artisans }\end{array}$ & Municipally-owned \\
\hline 17 & Otwocka 14 & $5001-10,000$ & $\mathrm{crm}$ & Production & Cultural & Private \\
\hline 18 & Siedlecka 47 & $30,000-50,000$ & $\mathrm{crm}+$ none & Production & Production & Perpetual usufruct \\
\hline 19 & Stalowa 34/Równa 1 & $2001-5000$ & rom & Unused $^{\mathrm{b}}$ & Unused & Municipally-owned \\
\hline 20 & Stalowa 67 & $1001-2000$ & None & Production & Multi-functional & Municipally-owned \\
\hline 21 & Stolarska 2/4 & $1001-2000$ & $\mathrm{crm}$ & Production & Unused & Perpetual usufruct \\
\hline 22 & Strzelecka 30/32 & $1001-2000$ & $\mathrm{rom}+\mathrm{crm}$ & Production & Unused, very bad repair & Private \\
\hline 23 & Szwedzka 2 & $>50,000$ & rom + none & Military & Multi-functional & Private \\
\hline 24 & Szwedzka 20 & $30000-50000$ & $\mathrm{rom}+\mathrm{crm}$ & Production & Multi-functional & Perpetual usufruct \\
\hline 25 & Śnieżna 3 & $500-1000$ & $\mathrm{crm}$ & Production & Multi-functional & Perpetual usufruct \\
\hline 26 & Targowa 82 & $500-1000$ & None & Residential $^{\mathrm{b}}$ & Multifunctional & Municipally-owned \\
\hline 27 & Wojnicka 4/Otwocka 1b & $5001-10,000$ & cro+ none & Production & Multi-functional & State-owned \\
\hline 28 & Zamoyskiego 4 & 15,000 & None & Offices & Unused & Private \\
\hline 29 & Ząbkowska 27/31 & $30,000-50,000$ & rom + none & Production & Multi-functional & Perpetual usufruct \\
\hline
\end{tabular}

Source: own work

In case of the various methods of heritage protection on the site towards the existing buildings all form of the protection (or lack of thereof) is described, starting from the most restricted

rom register of monuments (national level), crm communal record of monument

a It was not possible to establish the function above any doubt

b Former industrial function had been already replaced in the $1980 \mathrm{~s}$

c If not specified otherwise sites in perpetual usufruct are municipally-owned

mediocre or low heritage value regarding their architectural features. The entry in the register of monuments provides a very strict control from the regional and municipal heritage authorities. The entry in the communal record of monuments should ensure that at least the external appearance of the buildings will be preserved.
However, legal heritage protection regards only the architectural and strictly aesthetic values. It is our opinion that presented sites consist important part of cultural and social heritage. Industrial past, local identity of factory workers, manufactures and artisanship is also a crucial part of it. 
Sites localization is presented on Fig. 2. They create a sort of clusters, especially these located on the northern side of the main streets of the district (Wileńska St. and Solidarności Av.) and eastern railway line, paralel to Solidarności Av. There are 12 sites there, all within a few minutes walking distance one from another. In the eastern part of the area, south of Solidarności Av. there is less close-knitted cluster of 14 sites, three others located closer to the Vistula River.

All sites create very varied space of Praga district. Even if close to each other, they are embedded in a multifunctional urban structure, some of them hidden behind residential buildings, some very prominent and covering several joint plots of land. It is clear how the construction of the railway and the railway station (at the corner of Solidarności Av. and Targowa St.) influenced the industrial investment back at the time. Today, it makes the area well connected to other parts of the city, both by the local railway and the metro line, both accessible at the transport hub of the Wileńska railway/metro stations. Soon new metro stations will be opened, at Szwedzka St., in the vicinity of the locations No 20, 23 and 24.

Regarding the ownership status, the sites are approximately divided into three similar groups: 8 of 29 are municipally-owned (one of them is also partially owned by the private owner), 8 belong to private entities or natural persons (one of them partially owned by the municipality), one is state-owned and 12 are in perpetual usufruct, either from the municipality or the state. It was a form of public ground lease, established in Poland during the centrally planned regime. This long-term land lease grants the lessee the right to keep benefits derived

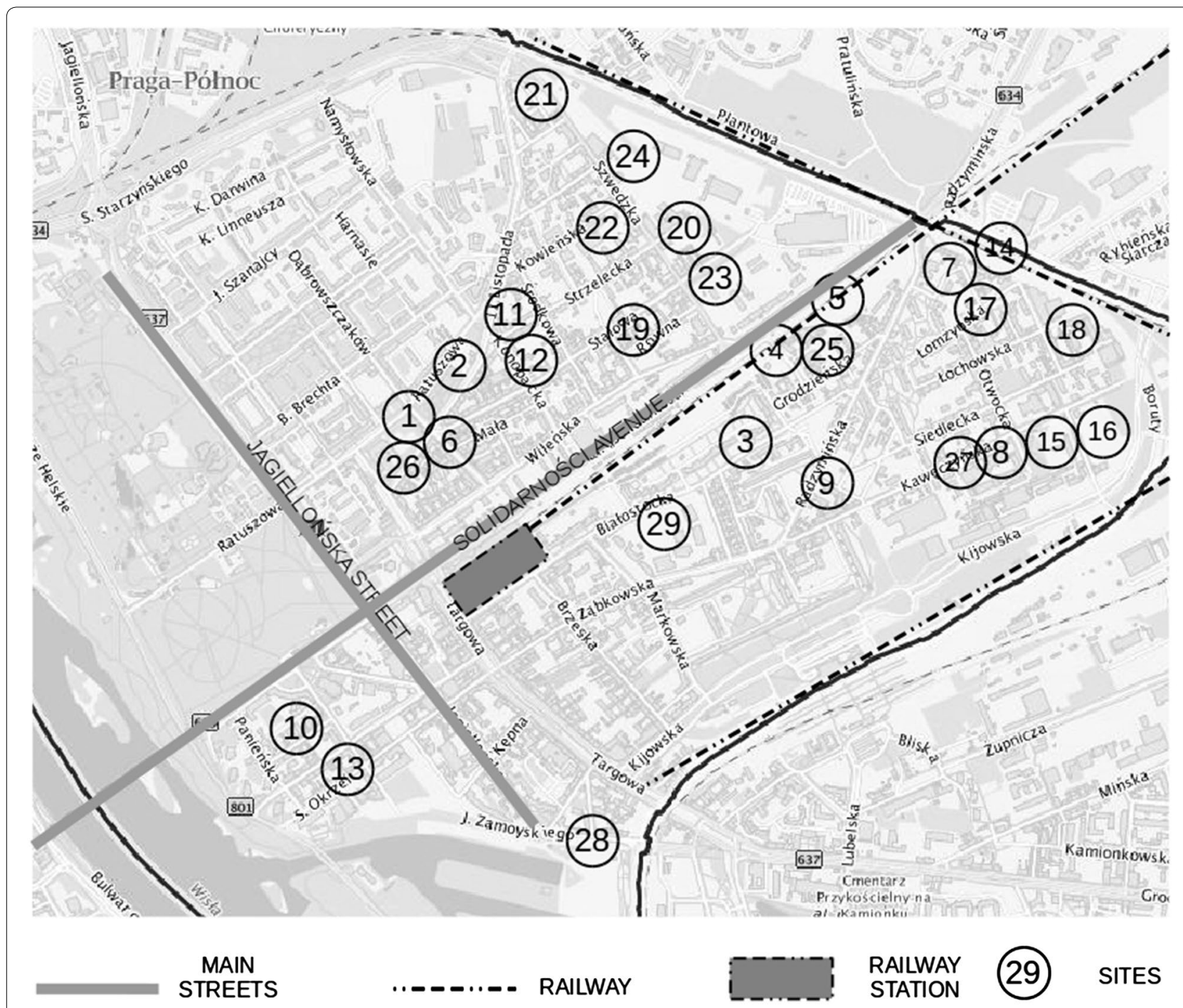

Fig. 2 Analyzed sites in Praga North district (Source: own work on the map from http://mapa.um.warszawa.pl/ (Accessed 03.07.2019)) 
from the land. It can be granted only by the State Treasury (on land located in urban areas or included in urban spatial development plans) or by communes or their unions (on any land, urban or rural). In practice municipality has usually treated such sites as a private property, regarding public investment or any other form of land use, except from the due taxes. Today, by the government new legislation, all such properties are to become private, owned by the lessee, but the regulations are still in the process of clarification and regard mostly natural persons. It may reverse the ownership proportion of the analyzed sites, from approx. $2 / 3$ owned by the municipality and $1 / 3$ private to $2 / 3$ privately-owned sites. Some sites are also under the restitution claims. They destabilize the situation of the sites, for one reason because of the constant changes in the status (claims recognized or rejected, new claims). Additionally, they restrict the municipality willingness or legal possibility to invest, as public sector may not provide funds for the private sites.

Regarding use, in 198922 of 29 sites operated as sites of production of various scale and characteristics (including warehouses). One site had already been abandoned, some had been converted for other uses-one for the military use and 3 for the offices. One site was used for services, the use of another is impossible to establish beyond doubt with the available data. Currently, only three sites are still used uniquely or mainly for producing goods. The smallest one of them is a local bakery (No 7 in Table 1), established in the 1980s, with little Museum of Bread on the site. Nearby is located another one, producing machinery for bakeries (No 14 in Table 1). On one of the biggest sites of all (more than 30 thousand $\mathrm{m}^{2}$ ) is located Precision Machine Tools Factory "AVIA" S.A. (No 18 in Table 1) The factory was established in 1902 and is one of the oldest Polish industrial plants. It has been one of the leading Polish manufacturers of high-quality machine tools, with broad export, mostly to Germany. The factory benefits from the scale of the site and the opportunity to expand. Nine sites are unused, two of them with the legal decision to dismantle existing, dilapidating buildings and replace them with housing.

More than $1 / 3$ of the total number is multi-functional, one was converted for academic purposes, nine are unused, one functions as a cultural institution and two are converted into the residential buildings. Multi-functional sites demand more in-depth analysis and create the main basis for our argument. They are described in more details in further part of the paper.

\section{Drivers and outcomes of change-looking for patterns}

Complexity, heterogeneity and diversity seem to be the most significant pattern to be observed. There is almost no pattern linking the heritage value, ownership and current functions. Sites of higher and lower values are generally evenly distributed among the various owners. Unused sites belong both to the municipality and to the private owners, but the majority is publicly owned, either by the state or by the municipality. Unfortunately, also the sites in bad technical state comprise not only the sites of lower heritage value but also of the higher one.

Future adaptations, modernizations and other forms of transformations will decide not only the fate of these 29 sites but will strongly influence the whole area and the whole district. Such decisions will create future local identity and perception of former heritage. With this in mind we propose to divide the sites into five groups which illustrate the current tendencies:

- Abandoned/currently unused sites

- Industrial sites

- Residential sites

- Multi-functional sites

- Other.

Abandoned or currently unused sites (presented in Table 2) belong mostly to the municipality, some of them are in a poor technical state. Several public discussions

Table 2 Abandoned or currently unused sites

\begin{tabular}{|c|c|c|c|}
\hline No in Table 1 & Address & Function of the site & Ownership \\
\hline 5 & Grodzieńska 51 & Unused & Municipally-owned \\
\hline 6 & Inżynierska $5 b$ and $5 c$ & Unused, to be converted into the residential use (lofts) & Private \\
\hline 11 & Konopacka 17 & Unused, very bad repair & Municipally-owned \\
\hline 12 & Konopacka 19 & $\begin{array}{l}\text { Unused, (former factory dismantled, residential buildings with local } \\
\text { stores under construction) }\end{array}$ & Private \\
\hline 16 & Objazdowa 2 & Unused, planned to be converted into a cluster for artisans & Municipally-owned \\
\hline 19 & Stalowa 34/Równa 1 & Unused, very bad repair & Municipally-owned \\
\hline 21 & Stolarska 2/4 & Unused & Municipally-owned \\
\hline 22 & Strzelecka 30/32 & Unused, very bad repair & Private \\
\hline
\end{tabular}

Source: own work 
Table 3 Industrial sites

\begin{tabular}{|c|c|c|c|}
\hline No in Table 1 & Address & Function of the site & Ownership \\
\hline 7 & Jadowska 2 & Production, small bakery & Perpetual usufruct \\
\hline 14 & Łomżyńska 37 & Production, machinery for bakeries & $\begin{array}{l}\text { Co-ownership } \\
\text { Private/municipally-owned }\end{array}$ \\
\hline 18 & Siedlecka 47 & Production, precision machine tools factory & Perpetual usufruct \\
\hline
\end{tabular}

Source: own work

and consultations were held to decide their future character and use. Cultural functions dominate among municipal propositions for these locations, closely followed by new space for traditional artisans and modern manufacturers. One of them is to be used for municipal own administrative purposes. None of these ideas has yet been put into life. They may influence to great extent the possibility to create a "city of making" in Praga and to induce indigenous and strong economy. Private plans for the sites which are currently unused consist mostly of the upperclass housing, possibly with some local stores for the new inhabitants. Works are already on-going on one site.

The smallest group consists of the sites still operating as the places of production, summed up in Table 3 and more precisely presented above. They consist an important factor in the "productive city" or "city of making" model, and at the same time they provide the continuous identity to the area based on the industrial development. It is also worth mentioning that some production functions are still present on the multi-functional sites, unfortunately their majority is in their last months of the lease and it is already decided they will be replaced by other functions.

There are two already operating sites of residential use: at 9/11/13 Kawęczyńska St. (No 9 in Table 1) and 6 Krowia St. (No 13 in Table 1). They are both developers' investments and they reflect two various tendencies of such ventures. The first one is an adaptive re-use of the former factory converted into the lofts, accompanied by typical new housing. The other consists of new housing constructed on the site after dismantling the industrial premises. There are also sites currently under construction or at the stage of design also follow these two types of investments, lofts and new housing.

One site was converted for educational purposes and hosts now a private college, at 36 Kawęczyńska St. (No 8 in Table 1). It combines the adaptive re-use of the former industrial buildings with new buildings constructed for this purpose. Educational use is also present on the multi-functional sites. Another site has been used for the cultural purposes for several years now, at 14 Otwocka St. (No 17 in Table 1). It is privately owned site, on lease for other private entities which developed several cultural ventures since 1990s., from low-costs events, to corporate events to theater shows. Private education, similarly, as the culture venue at Otwocka Str. attract the broader public/students from Warsaw and beyond. In multi-functional venues the educational or artistic uses are also present, targeting various public.

Mixed use is a very characteristic feature and is present in more than $1 / 3$ of the sites. In several sites it was introduced spontaneously by the users, looking for the reasonably well located and yet not over-priced space. Several functions require the appropriate location for "dirty" or more noisy work, as car mechanics work or several types of repair shops. In other cases, it is important to have a small store, easily accessible from the street or with delivery area. Such space is not abundant in Warsaw, where, especially in the left-bank downtown it is common for the entrepreneurs to rent a flat in the tenant house for a studio or an office. However, more manual work and dependence on the visibility to clients make post-industrial location much more attractive. Additional factors comprise:

- Specific atmosphere, which is quite different in the premises constructed for work (production) than in the adapted flats (significant value expressed by several free-lancers, architects and designers).

- Proximity of other entrepreneurs, possibility of clustering, cooperation.

- Tradition of the area, both in symbolic but also practical terms-several clients perceive Praga as a cluster of craftsmanship, there are in fact people there whose skills are valuable for new ventures of similar character.

Some of the mixed-use sites indeed have the character of clusters, gathering compatible or complementary enterprises. Others serve ventures of nature very different from one to another, but still existing side by side with no visible conflicts or inconveniences. They provide diverse jobs and variety of city dwellers in the neighborhood. Good example of such site in former Brage factory at 2211 Listopada St. (No 2 in Table 1), hosting popular clubs, a hostel, a theater (lately relocated to another site), artisan shops (sewing, smithery) and a store with hairdresser accessories. Offices and small services are located mostly in buildings erected in 1920 and 1930, in better 
Table 4 Mixed use sites

\begin{tabular}{|c|c|c|c|}
\hline No in Table 1 & Address & Function of the site & Ownership \\
\hline & & Small-scale enterprises & \\
\hline 1 & 11 listopada 10a & $\begin{array}{l}\text { Multi-functional (poligraphic services, small-scale production) current } \\
\text { functions to be abandoned, future use unknown }\end{array}$ & Private \\
\hline 2 & 11 listopada 22 & $\begin{array}{l}\text { Multi-functional (hostel, restaurant, clubs, wholesale store, sewing ser- } \\
\text { vices, part of the site unused) }\end{array}$ & Municipally-owned \\
\hline 3 & Białostocka 42 & Multi-functional (offices, services, upholsterer, high-class bakery) & Private \\
\hline 4 & Grodzieńska 21/29 & Multi-functional (educational_—private college), car workshop & Perpetual usufruct \\
\hline 10 & Kłopotowskiego 11 & Multi-functional (several offices, including religion congregation's office) & Perpetual usufruct \\
\hline 15 & Objazdowa 1/Wojnicka 2 & $\begin{array}{l}\text { Multi-functional (offices, high quality cloth production, sewing services, } \\
\text { part of the site unused), currently planned to be converted into the } \\
\text { high-class multi-functional site (offices, stores, restaurants) }\end{array}$ & Perpetual usufruct (state-owned) \\
\hline 20 & Stalowa 67 & $\begin{array}{l}\text { Multi-functional (offices, services, car workshop and specialized tools } \\
\text { store) to be converted into the HQ of municipal Green Areas Manage- } \\
\text { ment }\end{array}$ & Municipally-owned \\
\hline 25 & Śnieżna 3 & Multi-functional (health care, charity services, cultural) & Perpetual usufruct \\
\hline 26 & Targowa 82 & $\begin{array}{l}\text { Multifunctional (residential front with social services, gastronomic ven- } \\
\text { ture employing people in difficult situation behind the main building) }\end{array}$ & Municipally-owned \\
\hline \multirow[t]{2}{*}{27} & Wojnicka 4/Otwocka 1b & Multi-functional (services_commercial and social; gym, car workshop) & State-owned \\
\hline & & Developers investments & \\
\hline 23 & Szwedzka 2 & $\begin{array}{l}\text { Multi-functional. Former industrial buildings used for conferences and } \\
\text { events; it is planned to construct private medical university premises } \\
\text { (including hospital and students quarters) }\end{array}$ & Private \\
\hline 24 & Szwedzka 20 & $\begin{array}{l}\text { Multi-functional (offices, services in former industrial buildings) and new } \\
\text { residential buildings }\end{array}$ & Perpetual usufruct \\
\hline 29 & Ząbkowska 27/31 & $\begin{array}{l}\text { Multi-functional. New buildings with stores, services, offices and residen- } \\
\text { tial functions }\end{array}$ & Perpetual usufruct \\
\hline
\end{tabular}

Source: own work

repair and more easily adaptable then spacious, 19th century buildings.

Several of the multi-functional sites are rented by micro- and small-scale enterprises, with goods and services addressed for low- or medium-income clientele. There are also three examples of a different nature, developers investments combining residential and commercial uses. Stores and restaurants are much more numerous on these sites, while production, repair or artisanship are much less present. These two groups are presented in Table 4.

Multi-functional sites tend to be privately-owned or managed. Municipal institutions are rather prone to establish single function on the premises, focusing mostly on cultural functions or creative class clusters. It is a gap in municipal policies as the mixed use prove to be both seek after and sustainable.

In the late 2018 and early 2019 some decisions were made which are going to change the landscape of Praga more profoundly. As presented in Table 4 some production or manual work/repair-based enterprises cannot continue on their current premises. One of the bestknown production enterprise, Yeti factory producing outdoor wear, located on the mixed-use site will probably be relocated to more peripheral districts of Warsaw, other workshops may follow. On the other hand, investments in upper-class housing is still expanding.

\section{On the cross-roads-where is Praga heading?}

Local and global character, as well as the features of the "productive city" and "consumerist city" need to be translated into specific, tangible and intangible aspects of Praga. To do that we need to assess which functions are of a local or supra-local character and which create part of the productive or consumerist city.

Several stores and services on the analyzed sites have local character. Some of them are only known to their long-term clients or visitors, as some artisans' services or rehearsal rooms. Such local character does not have to mean that all clients are Praga inhabitants, some have clients from other parts of Warsaw, but it is quite common that it is not a part of a common knowledge that they exist (e.g. artisans providing services for theaters or other cultural ventures). Several mixed-use sites are perceived as a "typical" or "traditional" Praga.

Production sites still operating present a variety in this respect-from small-scale local bakery to the machinery factory or sewing company of high quality 
with international network of clients and cooperation. However, they are rooted in Praga tradition, workforce and character of place. New ventures have more supralocal character. New housing is meant to attract higherincome clientele that is typically found in Praga, hotels, restaurants, new offices have similar character and target groups. Some owners make efforts, either for their own sake or under the conservator office's pressure, to include tangible heritage into their investments and to profit from the uniqueness and authenticity sought by some clients. Such ventures as Museum of Vodka in Koneser Center in former vodka factory may be seen as both preserving the heritage and presenting it to the broader, even international public. Koneser Center (No 29 in Table 1) may be an example of an effort to combine local and supra-local level. There are temporary markets for artisans and craftspeople visited by clients from Warsaw, Poland and abroad, who are attracted by the venue. Tangible and intangible elements are preserved to some extent, and the investment was presented in the international real estate competition. The heritage of Koneser factory, with its new use is also part of global competition, but on another market. The owners applied for the MAPIC Award (International Retail Property Market) in category of Retail Urban. The project (of which the architects are Juvenes Project and the developer-Liebrecht \& wooD Group and BBI Development) was short-listed, with three other projects from UK, Belgium and The Netherlands. Such combination of the local-international level is also present in some municipal documents (Revitalization Programme; Strategy 2030), although they are still in their planning stage, and it is to be seen what specific actions will follow.

Generally, most of the developer's investments were big-scale production sites in 1980s, manufacturing high quality paints, vodka and cosmetics, for Polish and external markets. They were strong factors in local identity and 3 of them has had high architectural values. The costs of preserving the sites were covered by prestigious functions, high-end offices, restaurants and hotels as in Koneser, at 27/31 Ząbkowska St. in former vodka factory. Heritage is present in a form of Museum of Vodka. Other buildings, of low heritage value, were easy to dismantle and to be replaced by modern housing, now dominating in this group. Such re-use is possible only for the sites which may provide profit from the real estate market and the change from manufacturing use to services, residential or consumerist attraction seems inevitable. To some degree such investments provide the mix of the residents and city dwellers and help to provide new image for the area. On the other hand, if they are not complemented by the investments for the former inhabitants, especially of less income, they are typical elements of possible complete gentrification.

It is evident, that production and manual-labor-based enterprises are disappearing from the analyzed area, replaced by more consumption-driven character of new ventures. As they are also of more expensive character, they attract new clients, in part they are with no doubt provided for the inhabitants of new housing, in part the targeted group consist of tourists. Praga entered the stage of a very dynamic change, in terms of ownership (perpetual usufruct and restitution claims pending), sites' uses and the structure of labor force and local community. It seems to be a breaking-point for some functions, mostly related to production. Internalization and gentrification are also present, with some effort to introduce local heritage into a new character of the district.

Several entrepreneurs find post-industrial sites and buildings as a favorable environment for their venture. Apart from a certain genius locci they possess specific qualities appreciated by small producers, craftspeople and artists. They are embedded in a space of a very dense and urban character, increasing the serendipitous meetings and cooperation. Varied scale makes it easier for different actors to find the store or studio answering their professional needs and to find a new place in the vicinity if the venture expands and decreases. Streets and public space, together with good transport and walking connections create an environment favoring easy and numerous visits from the clients and business partners. Post-industrial buildings need fewer remodeling works for use of heavy or noisy machinery. Therefore, there is no need to invent new uses, e.g. cultural for such sites, as there is a strong community prepared and eager to use it for professional purposes. The main obstacles in the opinion of these actors is poor technical state of several sites and difficulties in cooperation with the public administration. There is a variety of initiatives and ventures, creating the potential for both local and supra-local future character of the area, and for its varied character in terms of production and consumption.

\section{Conclusions}

29 analyzed sites present a broad variety of characteristics of formerly industrial sites, but very few of them still operating on the production basis. They aptly illustrate the transition period, with its laissez-fair policy, strong entrepreneurial attitude and lack of strong public players. Change of their use reflects the more general shift in the economy, on the global level, as well as on the country and the local level.

Currently, some production of "city of making" entrepreneurship is still present in Praga. It may benefit from the expanding market, with new inhabitants and 
visitors of higher income, or new connection through the appearing international ventures and investors interest. It would be still possible to combine the elements of production and consumption in local economy, providing goods and services from people of various paths of life, various incomes, interests and background. It could be an alternative to what in fact seems to be happening, namely replacing former uses or former type of economy by another. Such a change, assessed but the authors as decreasing the heritage value of the area and its socioeconomic sustainability, results unfortunately also form the municipal decisions. The comprise the loss of the lease by production-oriented companies and approval for replacing the post-industrial buildings by residential ones. The heterogeneity of the area may decrease, with the irreversible loss of grass-root activities and continuity of skills and labor traditions. Municipal or private actors may try to replace or renew them (as some examples or programmes already indicates) but it will be more difficult to re-build such community then to preserve the existing networks and pools of skills. The most fragile part of the heritage is the heterogeneity of scale and types of buildings, which served production purposes in the past. They create a valuable potential for new artisans, artists and enterprises of "city of making". When they are lost, Praga will lose a lot of its tradition but also appeal for future generations of "the makers".

The analysis of the post-industrial sites in Praga confirm the hypothesis of lack of coherent and strategic urban policy regarding this part of Warsaw as well as former industrial areas in general. In spite of the presence of strategic documents and programmes it is not possible to find any consistency in the use of the municipally-owned sites, their former privatization or current use. Currently ongoing programmes (Strategy 2030; Revitalization Programme) give suggestions about possible expanding artisanship in Praga, but with the heritage space disappearing it may be difficult to go beyond some single and loosely connected points of activities. Still, the comparatively high level of municipal ownership and variety of scale and mixed use provide a field for future activities and cooperation. Grass-root activities encompassing craftsmanship and manual production are supported by the programmes of Museum of Praga.

Heritage protection, which is created on the city and voivodship level but results from the country-level legislation, presents the only consistent pattern. However, it is generally of a very traditional and conservative nature and does not provide the framework for more innovative and contemporary approach. It focuses mostly on the preservation of the tangible elements of architecture. There is also a significant lack of inter-sectoral cooperation, private-public partnership or multi-level governance which could prove extremely fruitful in such area. Urban policies have been to a great extent a zeroone nature, either giving a free hand to the market forces, either taking the whole responsibility, including funds and ideas for future development.

It may seem ironic, but during the centrally-planned economy, Praga factories provided the national significance to this area. Some of the local production had even an international potential, the most famous example being the vodka factory Koneser. Evidently, not all forms of production could compete with Western markets after the 1989. A complex of factors reduced the industrial potential of Praga, which in the 1990s and early years 2000 shrank to the forgotten and ill perceived "backwoods" of Warsaw. Now it is rather consumerist character of Praga which attracts broader attention. This illustrates the shift from city of production to the city of consumption. Both private and public sector seek new use and new image for Praga through upscaling post-industrial heritage. Municipality aims at attracting the international creative class, but also tourists and developers to construct new housing for higher middle class. Cultural use is also omnipresent in municipal strategies.

We argue that Praga may benefit from its development delay. Its heritage and built environment vary in terms of architectural value, size and character. Therefore, it provides a natural environment for a mixed use, in terms of ownership, tangible and intangible business ventures, production and services, market ventures and various forms of cooperation. Its new identity, rooted in heritage of production and manufacturing, should provide dignified alternative to consumerist city, gentrification and growing inequalities. Praga may be a new "city of making" growing alongside with artistic and innovative enterprises.

Unused sites provide a very specific opportunity for the urban policies which could create new values and new local identity. To this goal urban policies should focus on the potential of the existing built environment, to encourage the mixed use and co-create the new environment with local entrepreneurs, artisans and other active stakeholders. Industrial heritage in Praga may prove to be a crucial asset in its redevelopment if used wisely.

\section{Acknowledgements \\ Not applicable.}

\section{Authors' contributions}

AL carried out most of the research on the case-studies. KS provided the theoretical framework, carried out part of the filed research and interviews, and drafted the manuscript. Significant part of the paper and the conclusions are the fruits of a common research and discussions. The content of the manuscript has not been published or submitted for publication elsewhere. Both authors read and approved the final manuscript. 


\section{Funding}

Not applicable. No specific funding was granted for the study.

\section{Availability of data and the materials}

The data supporting the conclusions are included within the article.

\section{Competing interests}

The authors declare that they have no competing interests.

\section{Author details}

${ }^{1}$ Warsaw School of Economics, Warsaw, Poland. ${ }^{2}$ Muzeum Warszawskiej Pragi, Warsaw, Poland.

Received: 26 September 2018 Accepted: 14 August 2019

Published online: 07 September 2019

\section{References}

Carter DK (ed) (2016) Remaking post-industrial cities: lessons from North America and Europe. Routledge, Abingdon

Castells M (1996) The rise of the network society. The information age: economy, society, and culture, vol 1. Information age series. Blackwell, London

Castells M (1997) Power of identity: the information age: economy, society, and culture. Blackwell Publishers Inc, London

Castells M (2011) The rise of the network society, vol 12. Wiley, New York

City of Making. Cities report (2018) http://www.citiesofmaking.com. Accessed 20 Aug 2018

Drucker P (2001) Special report. The next society. The economist, 52, November 3rd 2011. https://www.economist.com/special-report/2001/11/03/ the-next-society. Accessed 29 Aug 2019

Duvernoy I, Zambon I, Sateriano A, Salvati L (2018) Pictures from the other side of the fringe: urban growth and peri-urban agriculture in a post-industrial city (Toulouse, France). J Rural Stud 57:25-35

Florida R (2005) Cities and the creative class. Routledge, Abingdon

Geppert A (2014) Planning systems facing heritage issues in Europe: from protection to management, in the plural interpretations of the values of the past. Eur Spat Res Policy 21(2):9-12

Glaeser EL, Kallal HD, Scheinkman JA, Shleifer A (1992) Growth in cities. J Political Econ 100(6):1126-1152

Glaeser EL, Kolko J, Saiz A (2003) Consumers and cities. In: Clark TN (ed) The city as an entertainment machine (Research in Urban Policy), vol 9. Emerald Group Publishing Limited, Bingley, pp 177-183

Gomez MV (1998) Reflective images: the case of urban regeneration in Glasgow and Bilbao. Int J Urban Reg Res 22(1):106-121

Gómez MV, González S (2001) A reply to Beatriz Plaza's 'The GuggenheimBilbao Museum Effect'. Int J Urban Reg Res 25(4):898-900

Gorzelak G, Jałowiecki B (2007) Co trzeba zrobić w Warszawie? Uwagi wstępne. Uniwersytet Warszawski EUROREG. http://www.strategia.um.warszawa.pl. Accessed 16 Nov 2016

Gorzelak G, Jałowiecki B, Smętkowski M (2009) Obszary metropolitalne w Polsce: problemy rozwojowe i delimitacja. Raporty i analizy EUROREG $1 / 2009$

Hess DJ, Gottlieb R (2009) Localist movements in a global economy: sustainability, justice, and urban development in the United States. MIT Press

Holgersen S (2015) Crisis and the post-industrial city: or is M almö building yesterday's city tomorrow, again? Tijdschrift voor economische en sociale geografie 106(3):231-245
Homs C (2007) Localism and the city: the example of 'urban villages'. Int J Incl Democr 3(1):1-8

Jacobs J (1970) The economy of cities. Vinatage

Katz B, Nowak J (2018) The new localism: how cities can thrive in the age of populism. Brookings Institution Press, Washington

Kennedy C (2011) The evolution of great world cities: urban wealth and economic growth. University of Toronto Press, Toronto

Keynes JM (1936) The general theory of employment, interest, and money. Palgrave Macmillan, Cham

Kula M (2011) Przeprowadzki stolic. Studia Regionalne i Lokalne 12(43):5-19

Lever WF (2017) Glasgow: policy for the post-industrial city. In: Managing the city, Routledge, pp 40-59

Ocejo RE (2017) Masters of craft: old jobs in the new urban economy. Princeton University Press

O'Connor J, Wynne D (2017) From the margins to the centre: cultural production and consumption in the post-industrial city. Routledge, Abingdon

O'Riordan T (ed) (2001) Globalism, localism, and identity: fresh perspectives on the transition to sustainability. Earthscan Publication Ltd, London

Patti D, Polyák L (eds) (2017) Funding the cooperative city: community finance and the economy of civic spaces. Eutropian Research \& Action Cooperative City Books, Vienna

Perruchini M (2018) Nouveaux Artisans. Portrait d’une génération qui bouscule les codes. Eyrolles, Paris

Plaza B (2000) Evaluating the influence of a large cultural artifact in the attraction of tourism: the Guggenheim Museum Bilbao case. Urban Aff Rev $36(2): 264-274$

Plaza B (2007) The Bilbao effect (Guggenheim Museum Bilbao). http://mpra. ub.uni-muenchen.de/12681/. MPRA Paper No 12681, posted 13. January 2009 06:57 UTC

Plaza B (2008) On some challenges and conditions for the Guggenheim Museum Bilbao to be an effective economic re-activator. Int J Urban Reg Res 32(2):506-517

Revitalization Programme. Zintegrowany Program Rewitalizacji m.st. Warszawy do 2022 roku, Załącznik do Uchwały Rady m.st. Warszawy z dnia 17.09.2015 w sprawie przyjęcia Zintegrowanego Programu Rewitalizacji m.st. Warszawy do 2022 roku

Sadowy K (2018) Labour market in Warsaw problematic areas of Praga. Structural change, bottom-up activities and municipal policies. J Manag Financ Sci 11(32):53-70

Sassen S (2016) The global city: strategic site, new frontier. In: Managing urban futures. Routledge. pp 89-104

Savitch HV (2014) Post-industrial cities: politics and planning in New York, Paris, and London, vol 935. Princeton University Press, Princeton

Schumpeter JA (2010) Capitalism, socialism and democracy. Routledge, Abingdon

Strategy 2030. Strategia 2030. Projekt do konsultacji społecznych 2017, Urząd m. st. Warszawy, Warszawa

Veblen T (1899) The theory of the leisure class. History of economic thought books. Routledge, Abingdon

Warsaw Maps. http://mapa.um.warszawa.pl/. Accessed 20 Apr 2019

Zukin S, Kasinitz P, Chen X (2016) Global cities, local streets everyday diversity from New York to Shanghai. Routledge, Abingdon

\section{Publisher's Note}

Springer Nature remains neutral with regard to jurisdictional claims in published maps and institutional affiliations. 